DOI https://doi.org/10.18551/rjoas.2020-10.14

\title{
PHENOTYPIC PERFORMANCES AND GENETIC PARAMETERS OF QUANTITATIVE CHARACTERS OF BLACK RICE LINES RESULTED FROM PEDIGREE SELECTION
}

\author{
Aryana I.G.P.M., Sudharmawan A.A.K., Aryani I.G.A.U., Ernawati N.M.L., \\ Santoso B.B., Wangiyana W.* \\ Faculty of Agriculture, University of Mataram, Mataram, Indonesia \\ *E-mail: w.wangiyana@unram.ac.id
}

\begin{abstract}
This study aimed to determine phenotypic performance, heritability value, genetic diversity, and genetic advance of black rice lines resulted from Pedigree selection. The field experiment was carried out on an irrigated ricefield in the experimental farm of the Faculty of Agriculture, University of Mataram, located in Nyiurlembang Village, West Lombok, Indonesia, from June to November 2019. The experiment was designed according to Randomized Complete Block Design, with three blocks and 25 treatments consisting of 23 black rice lines (G1 to G23) and two parent varieties, i.e. the white rice variety "Situ Patenggang" (G24) and the black rice variety "Baas Selem" (G25). The results indicated that G1, G2, G8, and G20 were promising lines having high grain yields (7-8 t/ha) with long panicles, large number of filled grains, high weight of 100 grains, and high grain yield per clump. They also showed high values of heritability on days to harvest, plant height, number of productive tillers, panicle length, and number of filled grain per panicle; high values of genetic diversity on number of productive tillers, number of filled and unfilled grains per panicle, and grain yield per clump; and a high value of genetic advance on number of filled grains per panicle.
\end{abstract}

\section{KEY WORDS}

Genetics, grains, heritability, productivity, selection.

Rice (Oryza sativa L.) is one of the most important food sources needed by the majority of the world's population, especially in Indonesia. Based on the color of the rice, there are white rice, red rice and black rice. Black rice is functional rice that contains the highest concentration of anthocyan pigment compared with rice of other colors. Black rice could increase body resistance to disease, repair liver damage, reduce cholesterol in the blood, prevent kidney function disorders, and prevent cancer or tumors [1], [2].

The existence of black rice is increasingly rare because it is dominated by the cultivation of high-yielding varieties of modern, ideal, and white hybrids. There are several characteristics of black rice plants that make farmers unlike to cultivate them, which include high plant habitus, long days to harvest and low yield potential [3]. To improve the characteristics of black ice ("Baas Selem") towards ideal plant height, high productivity, large grain size, and early maturity, single cross (followed with Pedigree selection) with the white rice variety "Situ Patenggang", an early maturity and high yielding variety, has been carried out [4].

Pedigree selection is a selection method in segregated populations resulted from cross-breeding processes. This selection is carried out on self-pollinating plants with the aim of obtaining new varieties by combining the desired genes from two or more genotypes. Through this selection, there is an increase in the gene frequency of the desired alleles so that there is a shift in the mean population value to a better direction. This selection is applied if the selected traits have high heritability values on such a character as harvest age, plant height, and others, while quantitative characters such as crop yields generally have low heritability values, so pedigree selection is less effective [5], [6].

The lines resulted from the pedigree selection need to be studied for their phenotypic performance and genetic parameters. The phenotypic performance of a plant can be assessed based on its morphological characteristics. Assessment of these traits can be done 
by utilizing a variety of phenotypes in these plants. The diversity of phenotypic characters is the diversity of the appearance of plant traits resulted from an interaction between genetic and environmental factors [7].

The chances to produce new high yielding varieties are greater if the phenotypic diversity is high. The phenotypes expected in rice plants vary but are focused on days to flowering, low plant height, panicle length, number of filled grains, 1000 grain weight and yield potential [8].

Genetic parameters, consisting of genetic diversity, heritability and genetic advance, are essential measures for the success in applying a plant breeding program [9]. Genetic diversity can increase the chances of getting a better genotype through selection. Hetability is a genetic parameter that shows the proportion of genetic relative to phenotype variances of a variety, which indicates if the traits can be inherited in the next generation [6]. According to Acquaah [9] heritability determines the progress of selection, i.e. the greater the heritability value, the greater the selection progress that is achieved and the faster the superior varieties can be released, or vice versa.

This study aimed to determine the phenotypic performance, the values of genetic diversity, heritability, and genetic advance in the pedigree-selected black rice lines.

\section{MATERIALS AND METHODS OF RESEARCH}

The experiment was carried out in a technically irrigated paddyfield located in Nyiurlembang Village of Narmada District, West Lombok (Indonesia), from June to November, 2019. The field experiment was arranged based on a Randomized Complete Block Design, with two blocks (replications) and 25 treatments, consisting of 23 black rice lines (G1 through G23), and their parent genotypes, i.e. the white rice variety "Situ Patenggang" (G24) and the black rice variety "Baas Selem" (G25).

The seedlings of 20 days old were transplanted onto the experimental plots with spacing of $25 \mathrm{~cm} \times 25 \mathrm{~cm}$. Basic fertilization was done using $300 \mathrm{~kg} / \mathrm{ha}$ Ponska (NPK 15-115) 7 days after transplanting (DAP). The next fertilizion was done at 30 DAP using 100 $\mathrm{kg} / \mathrm{ha}$ Urea, followed by another fertilization at 50 DAP using $100 \mathrm{~kg} / \mathrm{ha}$ Urea. Other crop maintenance was done based on the optimum cultivation of rice.

Variables observed were days to harvest, plant height, panicle length, number of productive tillers, number of non-productive tillers, number of filled and unfilled grains per panicle, weight of 100 grains, grain yield per clump, and per ha. Data were analyzed with analysis of variance (ANOVA) using SAS and Duncan Multiple Range Test at $5 \%$ level of significance for mean differences. The coefficient of genetic diversity (KKG) was calculated according to Syukur et al. [6], heritability in broad sense was calculated according to the formula used by Aryana [10], and Expected Genetic Progress (KGH) was calculated according to the formula used by Syukur et al. [6].

\section{RESULTS AND DISCUSSION}

Growth and yield components. The results of ANOVA on the variables measured showed that there were significant differences between genotypes in days to flowering, days to harvest, plant height, number of productive tillers per clump, panicle length, number of filled grains per panicle, weight of 100 grains, grain weight per clump, and grain yield per ha, but not on the number of non-productive tillers per clump, and the number of unfilled grains per panicle (Table 1).

The genotypes having the ealiest maturity were G21, G22, and Situ Patengang (G24), i.e. 112 days after sowing (DAS), while the lines of $\mathrm{G} 1, \mathrm{G} 2$, and $\mathrm{G} 13$ were the latest maturity of 118 DAS. Based on the classification of maturity dates from IRRI [11], all lines tested here were under the criteria of early maturity (105-124 DAS). However, according to Widyayanti et al. [12], the longer the life cycle of a plant, the greater the production of biomass and crop yields, as can be seen from Table 3 that G1 and G1 showed the highest grain yield and the 
latest maturity (Table 2), but in contrast G4 with the second latest maturity showed the lowest grain yield (Table 3 ).

Table 1 - Summary of ANOVA results on the variables observed

\begin{tabular}{lllll}
\hline No. & Variables & F calc. & Probability & Significance \\
\hline 1 & Days to harvest & 2.87 & 0.006 & $\mathrm{~S}$ \\
2 & Plant height & 11.9 & 0.000 & $\mathrm{~S}$ \\
3 & Number of productive tiller per clump & 3.01 & 0.004 & $\mathrm{~S}$ \\
4 & Number of non-productive tiller per clump & 0.72 & 0.779 & $\mathrm{NS}$ \\
5 & Panicle length & 3.25 & 0.002 & $\mathrm{~S}$ \\
6 & Number of filled grains per panicle & 4.54 & 0.002 & $\mathrm{~S}$ \\
7 & Number of unfilled grains per panicle & 0.58 & 0.903 & $\mathrm{NS}$ \\
8 & Weight of 100 grains & 4.04 & 0.000 & $\mathrm{~S}$ \\
9 & Grain weight per clump & 2.06 & 0.040 & $\mathrm{~S}$ \\
10 & Yield (dry grain weight) & 2.04 & 0.043 & $\mathrm{~S}$ \\
\hline
\end{tabular}

Table $F$ at $\alpha=0.05=1.98$

Note: $S=$ Significant NS $=$ Non Significant .

The tallest was G20 with plant height $136.2 \mathrm{~cm}$ while Situ Patengang (G24) was the shortest plant $(106.8 \mathrm{~cm})$. Based on the plant height category of IRRI [11], the parents, i.e. Situ Patenggang (G24) and Baas Selem (G25) were still in the category of short height $(<110$ $\mathrm{cm}$ ), while G7, G8, G17, G18, G19 and G20 were in the tall category (>130 cm ), and other lines were in the medium category $(110-130 \mathrm{~cm})$. In terms of the number of productive tillers per clump, G10 (17.3 tillers) was the highest, whereas Situ Patenggang (G24) produced the least number of productive tillers per clumps (10.1 tillers). Unfortunately, although G10 produced the highest number of productive tillers, its grain yield was much lower than in G2 having almost the same number of productive tillers as that of G10. The low yield obtained by the G10 was most probably due to low panicle length and the low number of filled grains (Table 3).

Table 2 - Mean values of harvest age, plant height, number of productive tillers, and number of nonproductive tillers of black rice genotype

\begin{tabular}{|c|c|c|c|c|}
\hline $\begin{array}{c}\text { Lines } \\
\text { (genotypes) } \\
\end{array}$ & $\begin{array}{l}\text { Days to harvest } \\
\text { (DAS) }\end{array}$ & $\begin{array}{l}\text { Plant height } \\
(\mathrm{cm})\end{array}$ & $\begin{array}{c}\text { Productive tiller number } \\
\text { per clump }\end{array}$ & $\begin{array}{c}\text { Non-productive tiller number } \\
\text { per clump }\end{array}$ \\
\hline $\mathrm{G} 1$ & $118.0 a^{11}$ & $124.8 \mathrm{~cd}$ & 12.2 cdefg & 0.0 \\
\hline G2 & $118.0 \mathrm{a}$ & $129.8 \mathrm{abc}$ & 10.9 efg & 0.0 \\
\hline G3 & $117.5 a b$ & $132.0 \mathrm{abc}$ & 13.3 bcdefg & 0.0 \\
\hline G4 & $117.5 \mathrm{ab}$ & 120.0 def & 14.1 abcde & 0.0 \\
\hline G5 & $116.0 \mathrm{abc}$ & $113.6 \mathrm{fg}$ & $10.3 \mathrm{fg}$ & 0.1 \\
\hline G6 & $116.0 \mathrm{abc}$ & 120.3 def & 11.2 defg & 0.0 \\
\hline G7 & $117.5 \mathrm{ab}$ & $135.2 \mathrm{ab}$ & 13.1 bcdefg & 0.0 \\
\hline G8 & $116.0 \mathrm{abc}$ & $132.6 \mathrm{abc}$ & $14.7 \mathrm{abcd}$ & 0.0 \\
\hline G9 & $114.5 \mathrm{abcd}$ & $112.8 \mathrm{fg}$ & $16.3 a b$ & 0.3 \\
\hline G10 & $114.5 \mathrm{abcd}$ & $107.5 \mathrm{~g}$ & $17.3 \mathrm{a}$ & 0.2 \\
\hline G11 & $114.5 \mathrm{abcd}$ & $107.8 \mathrm{~g}$ & 14.4 abcde & 0.1 \\
\hline G12 & $114.0 \mathrm{bcd}$ & 115.4 efg & $15.9 a b$ & 0.0 \\
\hline G13 & $118.0 \mathrm{a}$ & $112.2 \mathrm{fg}$ & $16.2 \mathrm{ab}$ & 0.3 \\
\hline G14 & $116.0 \mathrm{abc}$ & 120.4 def & 13.8 abcdef & 0.1 \\
\hline G15 & $113.0 \mathrm{~cd}$ & 119.4 def & 14.0 abcde & 0.2 \\
\hline G16 & $115.5 \mathrm{abcd}$ & $128.6 \mathrm{abcd}$ & 13.6 bcdefg & 0.2 \\
\hline G17 & $115.5 \mathrm{abcd}$ & $132.5 \mathrm{abc}$ & 13.3 bcdefg & 0.1 \\
\hline G18 & $115.5 \mathrm{abcd}$ & $134.4 a b$ & 13.8 abcdef & 0.0 \\
\hline G19 & $115.5 \mathrm{abcd}$ & $132.8 \mathrm{abc}$ & 13.5 bcdefg & 0.0 \\
\hline G20 & $113.0 \mathrm{~cd}$ & $136.2 \mathrm{a}$ & $15.2 \mathrm{abc}$ & 0.0 \\
\hline G21 & $112.0 \mathrm{~d}$ & $126.4 \mathrm{bcd}$ & 13.2 bcdefg & 0.2 \\
\hline G22 & $112.0 \mathrm{~d}$ & $123.6 \mathrm{cde}$ & 13.6 bcdefg & 0.2 \\
\hline G23 & $117.5 \mathrm{ab}$ & 119.9 def & $15.5 \mathrm{abc}$ & 0.0 \\
\hline G24 & $112.0 \mathrm{~d}$ & $106.8 \mathrm{~g}$ & $10.1 \mathrm{~g}$ & 0.1 \\
\hline G25 & $116.0 \mathrm{abc}$ & $108.9 \mathrm{~g}$ & 14.3 abcde & 0.0 \\
\hline
\end{tabular}

Note: ${ }^{1)}$ values followed by the same letter are not significantly different based on $5 \%$ DMRT test; DAS=days after seeding. 
The longest panicle length was in the G21 $(28.8 \mathrm{~cm})$ while Baas Selem (G25) produced the shortest panicle $(23.6 \mathrm{~cm})$. Based on panicle length classification [13], all the genotypes tested were in the category of medium panicle length $(20-30 \mathrm{~cm})$. Plants that have a long panicle will produce more grains so that grain weight per clump and yield per ha could also be higher, as can be seen in G2. However, G22 with almost the longest panicle in fact produced the second lowest grain yield per ha (Table 3).

The highest number of filled grains per panicle was found in Situ Patengang (G24), which was 248.3 grains per panicle, while Baas Salem (G25) produced the least amount (101.2 grains). In general, the number of grains was closely related to panicle length [14]; the longer the panicle, then the greater number of grains per panicle. However, G21 that has a long panicle did not produce a large number of filled grains per panicle. In contrast, the number of unfilled grains per panicle was no significantly different between genotypes.

In contrast, weight of 100 grains and grain yield per clump or per ha were significantly different between genotypes tested. The highest weight of 100 grains was in G10 (3.24 g), while the lowest weight was in G18 $(2.71 \mathrm{~g})$. However, higher weight of 100 grains does not always mean higher grain yield, as can be seen from Table 3, that G10, G9, and G11 had the highest weight of 100 grains among the lines, but had lower yields compared with G18 which had the lowest weight of 100 grains. According to Fadjry et al. [15], measuring the weight of 100 grains is useful in determining grain size of a variety, because heavier 100 grains of a variety indicates larger grain size.

Table 3 - Mean values of panicle length, number of filled grains per panicle, number of empty grains per panicle, weight of 100 grains, grain weight per clump, yield of dry grains (ton/ha) in black rice lines

\begin{tabular}{|c|c|c|c|c|c|c|}
\hline $\begin{array}{c}\text { Lines/ } \\
\text { genotype }\end{array}$ & $\begin{array}{l}\text { Panicle length } \\
(\mathrm{cm})\end{array}$ & $\begin{array}{c}\text { Filled grain number } \\
\text { per panicle }\end{array}$ & $\begin{array}{c}\text { Unfilled grain } \\
\text { number per panicle }\end{array}$ & $\begin{array}{l}\text { Weight of } 100 \\
\text { grain }(\mathrm{g})\end{array}$ & $\begin{array}{l}\text { Grain yield per } \\
\text { clump }(\mathrm{g})\end{array}$ & $\begin{array}{c}\text { Grain yield } \\
\text { (ton/ha) }\end{array}$ \\
\hline $\mathrm{G} 1$ & 26.6abcd & $206.5 a b$ & 20.5 & 3.04bcde & 45.51abcd & $7.78 a^{1)}$ \\
\hline G2 & 26.9ab & 199.3ab & 15.1 & $3.05 \mathrm{bcd}$ & 40.54abcd & $7.61 \mathrm{ab}$ \\
\hline G3 & 26.1 bcde & 176.2bcde & 17.5 & 2.97cde & 48.58abcd & 6.90abcd \\
\hline G4 & $24.3 \mathrm{cdef}$ & 142.1defg & 13.7 & 2.89defg & 45.76abcd & $3.99 f$ \\
\hline G5 & $25.2 \mathrm{bcdef}$ & 178.6bcde & 12.3 & $2.95 \mathrm{cdef}$ & 30.29abcd & $5.32 \mathrm{bcdef}$ \\
\hline G6 & $26.7 \mathrm{abc}$ & 159.4bcdef & 24.5 & 2.89defg & $36.34 \mathrm{~cd}$ & $5.05 \mathrm{cdef}$ \\
\hline G7 & 25.0 bcdef & 196.2bc & 17.5 & 2.90defg & $50.05 a b c$ & $5.00 \mathrm{cdef}$ \\
\hline G8 & 25.1bcdef & 207.6ab & 17.8 & $2.83 \mathrm{efg}$ & $57.22 \mathrm{a}$ & 7.29abc \\
\hline G9 & 25.6bcdef & 146.1cdefg & 16.4 & $3.21 a b$ & 41.41abcd & 5.70abcdef \\
\hline G10 & 24.7bcdef & $110.8 \mathrm{fg}$ & 19.3 & $3.24 a$ & $32.84 d$ & 5.53abcdef \\
\hline G11 & $25.8 \mathrm{bcdef}$ & 162.6bcde & 14.8 & 3.10abc & $32.92 d$ & 5.43abcdef \\
\hline G12 & $26.0 \mathrm{bcde}$ & 159.9bcdef & 18.1 & 2.93cdef & $39.71 \mathrm{bcd}$ & 5.33abcdef \\
\hline G13 & 26.0bcde & 165.0bcde & 17.0 & 3.03bcde & $39.60 \mathrm{bcd}$ & 5.68abcdef \\
\hline G14 & 24.6bcdef & 132.5efg & 14.3 & $3.00 \mathrm{cde}$ & 49.69abcd & 5.97abcdef \\
\hline G15 & 24.5bcdef & 171.4bcde & 15.0 & $2.96 \mathrm{cde}$ & $50.23 a b c$ & 5.32abcdef \\
\hline G16 & 25.8 bcdef & 201.3ab & 18.5 & $2.75 \mathrm{fg}$ & 49.24abcd & 6.12abcdef \\
\hline G17 & 25.0 bcdef & 190.3bcd & 17.2 & 2.86defg & 53.34abc & 5.90abcdef \\
\hline G18 & 25.3bcdef & 201.5ab & 22.7 & $2.71 \mathrm{~g}$ & 53.12abc & 6.63abcd \\
\hline G19 & 23.9ef & 166.3bcde & 13.0 & 2.90defg & 54.38ab & 6.27abcdef \\
\hline G20 & 24.3def & $187.9 \mathrm{bcd}$ & 16.8 & 2.88defg & $54.85 a b$ & 7.07abcd \\
\hline G21 & $28.8 \mathrm{a}$ & 162.3bcde & 16.7 & 3.02bcde & 48.75abcd & $6.87 \mathrm{abcd}$ \\
\hline G22 & $28.4 a$ & 166.4bcde & 20.0 & 3.03bcde & 45.72abcd & 4.18ef \\
\hline G23 & 26.1 bcde & 188.3bcd & 14.0 & $3.00 \mathrm{cde}$ & 54.16ab & 6.86abcd \\
\hline G24 & 25.3bcdef & $248.3 a$ & 11.9 & $3.00 \mathrm{cde}$ & 41.74abcd & 4.72def \\
\hline G25 & $23.6 f$ & $101.2 \mathrm{~g}$ & 11.3 & 3.02bcde & $38.12 \mathrm{bcd}$ & $6.45 a b c d e$ \\
\hline
\end{tabular}

Note: ${ }^{1)}$ values followed by the same letter are not significantly different based on $5 \%$ DMRT test.

In relation to grain yield, the highest yield per ha was in $\mathrm{G} 1(7.78 \mathrm{t} / \mathrm{ha})$ but it was not significantly different from that of Baas Selem or G25 (6.45 ton/ha) and other tested lines except G4 (3.99 t/ha), G5 (5.32 t/ha), G6 (5.05 t/ha), G7 (5.00 t/ha), G22 (4.18 t/ha), and Situ Patengang (G24) (4.72 t/ha). According to Aryana et al. [16], high yields in rice could be influenced by yield components such as number of productive tillers per clump, panicle length, number of filled grains per panicle, weight of 100 grains, and plant population per ha. The high yield was obtained on G1, G2, G8, and G20. It was due to having high yield components such as long panicles, large number of filled grains, weight of 100 grains and high grain weight per clump (Table 4). Based on those yield components, G1, G2, G8, and 
G20 produced higher yields than their two parents, so that they are can be examined further to develop new varieties.

Heritability, genetic diversity and genetic advance. Syukur et al. [6] grouped heritability values in broad sense into three classes, namely high heritability values if the value is higher than 0.5; moderate heritability if the value is between 0.2 and 0.5 , and low heritability if it is less than 0.2. Based on these, days to harvest, plant height, number of productive tillers, panicle length, and number of filled grains per panicle were in the chategory of high heritability (Table 4). High heritability values of plant height, number of productive tillers, panicle length, and number of filled grains per panicle were also found in the study of Kiani et al. [17], indicating that those traits were more influenced by genetic factors.

The characters showing moderate heritability values were weight of 100 grains, grain weight per clump and grain yield per ha (Table 4), which means that the performance of those black rice lines was controlled by genetic and environmental factors. This means that if the heritability is moderate then genetic advance cannot be obtained in that trait because the observed diversity is the influence of the environments and the dominant phenotypes [18].

The plant traits with low heritability values such as the number of non-productive tillers and the number of unfilled grains per clump (Table 4) indicated that the influence the environmental was greater than the genetic factors. This was caused by a deviation in a generation that allows some individual plants to show certain characteristics that are different from other plants. This deviation was thought to be influenced by environmental factors, such as pest attacks when the rice grain is in milk maturity stages; and it could be also affected by gene action that have an impact on the inheritance patterns [10]. Sutaryo and Sudaryono [19] stated that in characters with low heritability, selection was less effective because the appearance of plant phenotypes was more influenced by environmental factors than genetic factors.

The value of heritability has implications for the efficiency of selection and the selection method to be used. Selection efficiency is determined by the selection character used, where the selection character is chosen based on high heritability values [20]. In relation to selection, if the heritability value is high, the selection method used is the pedigree selection method, while if the heritability is low to moderate, then the selection method used is the bulk method. Heritability also determines progress of selection, the greater the value of heritability the greater the value of the selection progress achieved and the faster the superior varieties can be released or vice verse [21].

Table 4 - Values of heritability in broad sense, genetic diversity and genetic advance for the quantitative characters of black rice lines

\begin{tabular}{|c|c|c|c|c|c|c|}
\hline Characters & Heritability & Criteria & Genetic diversity & Criteria & Genetic advance & Criteria \\
\hline Days to harvest & 0.61 & High & 1.55 & Low & 1.70 & Low \\
\hline Plant height & 0.80 & High & 6.95 & Rather low & 8.69 & Medium \\
\hline Non-productive tiller number per clump & 0.00 & Low & 4.69 & Rather low & 0.16 & Low \\
\hline Productive tiller number per clump & 0.56 & High & 11.25 & High & 11.75 & Medium \\
\hline Panicle Length & 0.68 & High & 5.77 & Rather low & 6.66 & Low \\
\hline Filled grain number per panicle & 0.56 & High & 15.48 & High & 16.28 & High \\
\hline Unfilled grain number per panicle & 0.12 & Low & 12.93 & High & 6.30 & Low \\
\hline Weight of 100 grains & 0.49 & Medium & 3.62 & Low & 3.56 & Low \\
\hline Weight of grain per clumps & 0.42 & Medium & 11.80 & High & 10.72 & Medium \\
\hline Grain yield per ha & 0.35 & Medium & 10.31 & Rather high & 10.73 & Medium \\
\hline
\end{tabular}

The genetic diversity coefficient is classified into 4 groups: the genetic diversity coefficient is high, if the value between 11.61-15.48; the genetic diversity coefficient is high enough if the value between 7.74-11.61; and the genetic diversity coefficient is rather low if the value between 3,87-7.74; and the coefficient of genetic diversity is low if the value between 0 - 3.87 [6]. In our study, the high coefficient of genetic diversity was found in the number of productive tillers, the number of filled and unfilled grains, and the weight of grains per clump (Table 4). The same investigation was also found in Zen's study [22], which showed that the high coefficient of genetic diversity was found in the productive tiller per clump, the number of filled grains, and the grain weight per clump. 
High genetic diversity indicates that the traits tend to be influenced by many genes. Each gene contributes little to the phenotype and is cumulative, but the quantitative trait can also be influenced by environmental changes [23]. Characters with high genetic diversity value have the opportunity to be improved through selection, namely by giving flexibility in choosing the selected genotypes. The high coefficient of genetic diversity indicates a big influence of genetic factors on the appearance [19].

From Table 4 it can be seen that the coefficient of genetic diversity was found rather low in plant height, number of non-productive tillers, and panicle length. The coefficient value of genetic diversity was low found in the characters of harvest age and weight of 100 grains. A trait that has a very high and high genetic diversity value indicates that improvement by selection is possible for this trait. Traits that have high and very high diversity values could be said to have broad genetic diversity, and vice versa, traits that have low and medium diversity values could be said to have narrow genetic diversity. The higher the genetic diversity, the greater the chances of success for breeding programs. In addition, high diversity could also increase selection responses because selection responses are directly proportional to genetic diversity [3].

In our study, it was also found that the number of filled grain has a high heritability and high genetic advance. The estimated value of high heritability is not always followed by a high value of genetic advance. It depends on the selection intensity $(\mathrm{k})$ and additive variance. The estimated value of high heritability and high genetic advance was usually used for the selection of superior strains [24], [18]. In this study, the estimated value of heritability and the high value of genetic advance are found in the number of filled grain (Table 4). This indicates that the character was influenced by the action of additive genes [10] which also show that the character was influenced by genetic factors, so that selection could be done through a diversity of phenotypes [25].

The estimated value of high heritability with low values of genetic advance was found in the days to flowering, days to harvest, and panicle length (Table 4). This indicates that those characters were influenced by the action of non-additive genes [10]. It could also be interpreted that the days to flowering, days to harvest, and panicle length in the F2 lines have reached fixation of a stable age-regulating gene. The results of this study was the same as those of Akinwale et al. [25] against 20 Nigerian rice genotypes with heritability and genetic advance in days to flowering of $95.1 \%$ and 8.97 as well as $92.1 \%$ and 6.63 in days to harvest. Seyoum et al. [26] reported a heritability value of $90.16 \%$ and a genetic advance of 9.65 in the days to flowering, as well as $82.45 \%$ and 4.97 for the value of heritability and genetic advance for the days to harvest. Kristamtini et al. [3] also reported a high heritability value of $90.55 \%$ and a genetic advance of 1.87 in the days to flowering, as well as $90.72 \%$ and 1.87 in the days to harvest.

\section{CONCLUSION}

The black rice lines G1, G2, G8, and G20 were high in yields potential (7-8 t/ha) with high panicles length, filled grain number, weight of 100 grains, and grain yield per clump. Days to harvest, plant height, number of productive tillers, panicle length, and number of filled grains were characters that showed a high heritability. The number of productive tillers, number of filled grains, number of un-filled grains, and grain yield per clump were characters that were high in genetic diversity estimates, and the number of filled grains showed a high genetic advance.

\section{ACKNOWLEDGEMENTS}

The authors would like to thank to the Directorate of Research and Community Service of Directorate General of Research and Development of the Indonesian Ministry of Research, Technology and Higher Education for the "PTUPT" research grand to run this research project through Decentralization Research Scheme of 2018-2020. 


\section{REFERENCES}

1. Aryana I.G.P.M, Sudharmawan A.A.K., and Santoso B.B. 2017. Keragaan F1 and Heterosis Karakter Agronomis pada Beberapa Persilangan Padi Beras Merah [Performance of F1 and heterosis of agronomc characters in rd rice crosses]. J Agron. Indonesia, 45(3): 221-227.

2. Suardi D., and Ridwan I. 2009. Beras Hitam, Pangan berkhasiat yang belum populer. [Black rice, special quality food but not yet popular]. Warta penelitian and Pengembangan Pertanian. 31(2):9-10.

3. Kristamtini K., Sutarno S., Wiranti E.W., and Widyayanti S. 2016. Kemajuan Genetik and Heritabilitas Karakter Agronomi Padi Beras Hitam Pada Populasi F2 [Genetic Advance and Heritability of Agronomic Characters of Black Rice in F2 Population]. J. Penelitian Pertanian Tanaman Pangan, 35(2): 119-124.

4. Aryana I.G.P.M, Santoso B.B., Sudharmawan A.A.K., and Sukri M. 2019. Heritabilitas Galur Padi Beras Hitam (Oryza sativa L.) [Heritability of black rice (Oryza sativa L.) lines]. Jurnal Sain Teknologi Lingkungan. 5(1): 25-31.

5. Natsir M. 2001. Pengantar Pemuliaan Tanaman. Direktorat Jenderal Pendidikan Tinggi Departemen Pendidikan Nasional. Jakarta, Indonesia. 325 pp.

6. Syukur M., Sujiprihati S., Yunianti R. 2015. Teknik Pemuliaan Tanaman [Techniques of Plant Breeding]. Penebar Swadaya, Jakarta, Indonesia. 384 pp.

7. Hao X.B., Ma X.F., Hu P.S., Zhang Z.X., Sui G.M., and Hua Z.T. 2010. Relationship between plant type and grain quality of japonica hybrid rice in Northem China. Rice Sci., 17: 43-50.

8. Mara K. K. S., Purwoko B. S., Sulistyono E., and Dewi I. S. 2015. Penampilan Agronomi and Uji Toleransi Naungan Galur Dihaploid Padi Gogo Hasil Kultur Antera [Agronomic Performance and Shading Tolerance Evaluation of Upland Rice Dihaploid Lines Obtained from Anther Culture]. J. Agro. Indonesia, 43(1): 1-7. https://doi.org/10.24831/jai.v43i1.9580.

9. Acquaah G. 2012. Principles of plant Genetics and Breeding (2nded.). Oxfod, UK: WileyBlackwell Ltd.

10. Aryana, I.G.P.M. 2010. Uji keseragaman, heritabilitas, and kemajuan genetik galur padi beras merah hasil seleksi silang balik di lingkungan gogo [Test of homogeinity, heritability, and genetic advance of red rice lines resulted from backcross in upland environment]. Crop Agro, 3(1): 10-17.

11. IRRI. 2013. Standard Evaluation System for Rice. 5th Edition. Manila, Philippines. http://www.clrri.org/ver2/uploads/SES_5th_edition.pdf.

12. Widyayanti S., Basunanda P., Mitowihardjo S., and Kristamtini K. 2017. Keragaman Genetik and Heritabilitas Karakter Agronomi Galur F4 Padi Beras Hitam. Penelitian Pertanian Tanaman Pangan. 1 (3): 191-199.

13. Aryana I.G.P.M, and Santoso B.B. 2017. Budidaya Padi Gogo-Rancah Beras Merah [Cultivation of Dry-seeded-Flooded Red Rice]. Edisi 1. Arga Puji Press, Mataram, Indonesia.

14. Makarim A. K., and Suhartatik E. 2009. Morfologi and Fisiologi Tanaman Padi [Morphology and Physiology of Rice Plant]. Balai Besar Penelitian Tanaman Padi. Sukamandi, Indonesia.

15. Fadjry D., Arifuddin K., Syafruddin K., and Nicholas. 2012. Pengkajian Varietas Unggul Baru Padi yang Adatif pada Lahan Sawah Bukaan Baru untuk Meningkatkan Produksi > 4 ton/ha GKP di Kabupaten Merauke Provinsi Papua. Prosiding Insinas, Jakarta, Indonesia.

16. Aryana I. G. P.M, Sudantha I. M., and Bambang B. S. 2012. Daya Hasil and Penampilan Fenotifik Karakter Kuantitatif Galur-Galur F2BC4 Padi Gogo Beras Merah [Yield potential and phenotypic performance of quantitative characters of F2BC4 lines of upland red rice]. Prosiding InSINas. 2 (48): 5-11. 
17. Kiani S.H., Kazemitabar S.K., Jelodar N.A.B., and Ranjbar, G.A. 2013. Genetic Evaluation of Quantitative Trait of Rice (Oryza sativa L.) Using Generation Mean Analysis. Intl Agri Crop Sci. 5 (19): 2329-2336.

18. Aryana I.G.P.M. 2014. Teknik Pemuliaan Tanaman Padi Beras Merah [Techniques of Red Rice Breeding]. Arga Puji Press, Mataram, Indonesia.

19. Sutaryo and Sutaryono. 2010. Keragaman Fenotip and Beberapa Parameter Genetik Hasil and Karakter Agronomi Enam Padi Hibrida Di Lahan Kering Masam. Balai Pengkajian Teknologi Pertanian. Yogyakarta, Indonesia.

20. Suwarno P.M., Wirnas D., and Junaedi A. 2016. Kendali Genetik Toleransi Kekeringan Padi Sawah (Oryza sativa L.) [Genetic Control of Drought Tolerance in Rice (Oryza sativa L.)]. J. Agron. Indonesia, 44(2): 119-125.

21. Saputra H.E., Syukur M., and Aisyah S.I. 2014. Pendugaan daya gabung and heritabilitas komponen hasil tomat pada persilangan dialel penuh [Estimation of combining ability and heritability of yield components of tomato in complete diallel crosses]. J. Agron. Indonesia, 42(3): 203-209. https://doi.org/10.24831/jai.v42i3.9168.

22. Zen, S. 2017. Parameter Genetik Padi Sawah Dataran Tinggi [Genetic parameters of upland paddy rice]. Jurnal Penelitian Pertanian Terapan, 12(3): 196-201. https://doi.org/10.25181/jppt.v12i3.217.

23. Jamaeela A., Satoto, Sasmita P., Baliadi Y., Guswara A., and Suharna. 2014. Deskripsi Varietas Unggul Baru Padi [Description of Rice New Superior Varieties]. Badan Penelitian and Pengembangan Pertanian, Kementerian Pertanian, Jakarta, Indonesia.

24. Sanghera M., Sujiprihati S., and Yunianti R. 2013. Teknik Pemuliaan Tanaman [Techniques of Plant Breeding]. Penebar Swadaya. Jakarta, Indonesia. 384 pp.

25. Akinwale M.G., Gregorip G., Nwilene F., Akinyale B.O., Ogunbayo S.A., and Odiy A.C. 2011. Heritability and Correlation Coefficient Analysis for Yield and Its Components in Rice (Oryza sativa L.). African Journal of Plant Scienc, 5(3): 207-212.

26. Seyoum M., Alamerew S., and Bante K. 2012. Genetic Variability, Heritability, Correlation Ceofficient Analysis for Yield Related Traits in Upland Rice (Oryza sativa L.). J. Plant Sciences. 7: 13-22. 